Article

\title{
The Influence of the Morphology and Mechanical Properties of Polymer Inclusion Membranes (PIMs) on Zinc Ion Separation from Aqueous Solutions
}

\author{
Katarzyna Witt 1,*(D), Elzbieta Radzyminska-Lenarcik 1,* , Artur Kosciuszko ${ }^{2}$, \\ Magdalena Gierszewska ${ }^{3}$ (D) and Kamil Ziuziakowski ${ }^{4,5}$ \\ 1 Faculty of Chemical Technology and Engineering, UTP University of Sciences and Technology, \\ PL 85326 Bydgoszcz, Poland \\ 2 Faculty of Mechanical Engineering, UTP University of Sciences and Technology, PL 85796 Bydgoszcz, \\ Poland; Artur.Kosciuszko@utp.edu.pl \\ 3 Faculty of Chemistry, Nicolaus Copernicus University in Torun, PL 87100 Torun, Poland; mgd@chem.umk.pl \\ 4 Faculty of Chemistry, Adam Mickiewicz University in Poznan, PL 61614 Poznan, Poland; \\ ziuziakowski@gmail.com \\ 5 Przedsiebiorstwo Wielobranzowe GALKOR Sp. z o.o., PL 86010 Koronowo, Poland \\ * $\quad$ Correspondence: Katarzyna.Witt@utp.edu.pl (K.W); elaradz@utp.edu.pl (E.R.-L.); Tel.: +48-052-374-9055 (K.W.); \\ +48-052-374-9065 (E.R-L.)
}

Received: 30 November 2017; Accepted: 26 January 2018; Published: 30 January 2018

\begin{abstract}
The transport of $\mathrm{Zn}(\mathrm{II})$ ions across polymer inclusion membranes (PIMs) with acetylacetone (ACAC) or di(2-ethylhexyl)phosphoric acid $\left(\mathrm{D}_{2} \mathrm{EHPA}\right)$ as carriers was studied. Polymeric membranes consisting of polyvinylchloride (PVC) as the support, bis(2-ethylhexyl)adipate (DAO) as plasticizer, and ACAC or $\mathrm{D}_{2} \mathrm{EHPA}$ as ion carriers were investigated. The highest recovery factors for $\mathrm{Zn}(\mathrm{II})$ ions were observed in the case of a membrane containing $20 \%$ acac $(99.6 \%)$ and $60 \% \mathrm{D}_{2} \mathrm{EHPA}(56.3 \%)$. The prepared PIMs were examined using atomic force microscopy (AFM) techniques. Their mechanical properties were also determined. The influence of membrane morphology and mechanical properties on the zinc transport process was discussed.
\end{abstract}

Keywords: polymer inclusion membrane; metal ion separation; zinc(II); membrane mechanical properties; membrane morphology

\section{Introduction}

Polymer inclusion membranes (PIMs) were first prepared as Solvent Polymeric Membranes (SPMs), in 1963, by Bloch [1]. They were obtained by pouring out a polymer-carrier solution on paper. Although the enhancement of the membrane with paper improved its mechanical properties, it also hindered the diffusion of substances across the membrane. Twenty years later, Sugiura [2] improved this technique by introducing an additional component (plasticizer). The added component appeared to improve the polymer film in terms of mechanical strength, so paper was no longer required. To obtain a PIM, a clear quaternary solution (polymer, solvent, plasticizer, and carrier) is poured out on a glass plate and the solvent is allowed to evaporate. Then the membrane is placed in distilled water [3-5]. The obtained membranes are characterized by a negligible loss of carrier during pertraction. Moreover, in this procedure only low amounts of potentially hazardous chemicals are used. The chemical composition and membrane thickness can be easily modified [6]. PIMs are also characterized by higher mechanical strength and stability in comparison with other liquid membranes (SLMs) [7].

The role of the plasticizer is to improve the PIM in terms of elasticity and mechanical strength, as it penetrates into the polymer molecules and mitigates the intermolecular forces. This results in greater 
distances between the polymer molecules. Although a considerable number of plasticizers are available on the market, only a few of them were examined with regard to application in PIMs. The most frequently used plasticizers are: $o$-nitrophenyloctyl ether, $o$-nitrophenylpentyl ether, dioctyl adipate, dioctyl phthalate, and ethyltrialkylammonium chloride (Aliquat 336), which can act as a plasticizer and an anion carrier [8-10]. Polymer matrices made of polyvinyl chloride (PVC), polyvinylidenefluoride (PVDF), cellulose triacetate (CTA), or cellulose tributyrate (CTB) are used in the majority of studies devoted to PIMs $[8,11,12]$. Metal ion carriers in transport across PIMs are chemical compounds which are easily soluble in a liquid membrane, insoluble in aqueous solutions and which selectively and reversibly interact with the transported component [13]. Generally, the carriers are the same organic ligands as the extractants in solvent extraction [12,14-19].

The rapid development of industry, including its nuclear and hydrometallurgical branches, resulted in intensified studies on PIMs intended to be utilized in the processes of recovery, separation and concentration of metal ion from post-production waste solutions. The membranes are effectively used for the recovery of s-, p-, d-, and f-electron metal ions, but the PIMs which enable the recovery and separation of heavy metals enjoy the greatest interest $[8,9,20]$. The PIMs are also used for a more thorough purification of solutions formed in heavy-metal waste treatment by means of conventional methods (precipitation with slaked lime, ion exchange) [21].

Zinc and zinc compounds are used in various branches of industry. Metallic zinc is used for the preparation of anti-corrosive coatings for metal objects, production of alloys (such as brass), so-called dry cells (batteries) and anti-corrosive paints [22]. It takes between 4 and $9 \mathrm{~kg}$ of zinc to make a modern car. Zinc compounds are used in the production of medicines and cosmetics. $\mathrm{ZnO}$ is a component of varnishes and paints and is also used in production of tires [23,24]. Industrial wastes with a content of zinc, such as ashes, sludges, and liquid wastes, are a separate, very important issue: these are now regarded as metal-bearing materials. The obtaining of zinc from refuse using PIMs and other methods has been reported by a number of authors [25-27].

In 2000, the European Union established the Water Framework Directive. Its objective is for the EU member states to achieve good qualitative and quantitative status of water bodies and inland ecosystems which depend on them. The authors of the document had in mind to obtain a good ecological status of waters by various methods, also by reduction or, if possible, elimination of the emissions of highly hazardous substances formed in industrial processes, such as heavy metals, including lead, cadmium, chromium, copper, nickel, or zinc. This legislative measure clearly indicates the necessity of devising procedures resulting in a reduction of environmental emissions of these metals [28].

Given the growing demand for zinc, its high purchase price and the requirement to comply with environmental protection legislation, more than $30 \%$ of the metal's total production volume is obtained by means of various recycling methods [29].

Taking into account the above mentioned facts, there is a clear preference of zinc production methods which are based on the recycling of waste or solutions. Processes where PIMs with metal ion carriers are used are also of interest to researchers. The actual studies are intended to find new, effective metal cation carriers which will be selective and characterized by affinity to specific metals.

High selectivity for zinc is shown by organophosphorus derivatives, such as: di(2-ethylhexyl) phosphoric acid ( $\mathrm{D}_{2}$ EHPA) [30], di(2,2,4-trimethylpentyl)phosphinic acid (Cyanex 272) [31], di(2ethylhexyl)thiophosphoric acid (DTPA) [32], and di(2,2,4-trimethylphenyl)dithiophosphinic acid (Cyanex 301) [33]. Other potentially good carriers include derivatives of $\beta$-diketones, such as 1-phenyl-3-isoheptyl-1,3-propanedione (LIX-54) [34] and 1-phenyldecane-1,3-dione (LIX 54-100) [35]. LIX 54 as carrier is able to separate zinc and nickel from mildly alkaline environments. For example, one scientific report describes the transport of three metals $(\mathrm{Cd}, \mathrm{Pb}$, and $\mathrm{Zn})$ across membranes prepared from cellulose triacetate (CTA), 2-nitrophenyloctylether (2-NPOE) with $\mathrm{D}_{2} \mathrm{EHPA}$ or Aliquat 336 as the metal ion carriers. The feed and receiving phases were aqueous solutions of metal ions with $0.1 \mathrm{M} \mathrm{NaNO}_{3}$ and $0.1 \mathrm{M} \mathrm{HNO}_{3}$ (for $\mathrm{D}_{2} \mathrm{EHPA}$ ) or $0.5 \mathrm{M} \mathrm{NaCl}$ and $0.1 \mathrm{M} \mathrm{HClO}_{4}$ (for Aliquat 336), 
respectively. Zinc recovery rate from the metal ion mixture with the use of such membranes was $91.02 \%$ for the membrane with $\mathrm{D}_{2}$ EHPA and $56.34 \%$ for the membrane with Aliquat 336, respectively [36]. Kolev et al. used a PVC-based membrane with $\mathrm{D}_{2} \mathrm{EHPA}$ as carrier for zinc transport [37]. The feed phase was a solution of $22 \mathrm{mg} / \mathrm{L}$ of $\mathrm{Zn}(\mathrm{II})$ in $1.0 \mathrm{M}$ acetic acid and acetate buffer was used for maintaining a $\mathrm{pH}$ of 3.0. The receiving phase was 0.1 or $1.0 \mathrm{M} \mathrm{HCl}$.

In addition to known commercial carriers, new selective carriers are gaining increased interest; the materials are tested in various environments. As carriers of CTA-based membranes, Baczynska et al. used three phosphonium ionic liquids (Cyphos IL101, Cyphos IL104, Cyphos IL167) [38]. The authors of the present paper have determined that zinc is effectively transported through the investigated PIMs. Arslana et al. proved that sodium diethyldithiocarbamate (NaDDTC) is an effective, innovative zinc ion carrier, thanks to which transport across the membranes based on CTA and o-NPOE resulted in the $96 \%$ recovery of $\mathrm{Zn}$ [39]. The process was carried out at a $\mathrm{pH} 5.04$ and the receiving phase was $0.5 \mathrm{M} \mathrm{HCl}$.

In their earlier paper, the authors discussed zinc transport across a CTA-based membrane composed of o-nitrophenyl pentyl ether (o-NPPE) as plasticizer doped with 1-alkylimidazoles [40]. The process was effected from a ternary mixture comprising $\mathrm{Zn}(\mathrm{II})-\mathrm{Co}(\mathrm{II})-\mathrm{Ni}(\mathrm{II})$ and from a binary mixture of $\mathrm{Zn}(\mathrm{II})-\mathrm{Ni}(\mathrm{II})$. Better results of zinc recovery were obtained in the latter case ( $90 \%)$. In their next paper, the authors used carriers in the form of $\beta$-diketone derivatives [41]. The compounds proved to be effective in zinc recovery from the quaternary mixture $\mathrm{Zn}(\mathrm{II})-\mathrm{Cu}(\mathrm{II})-\mathrm{Co}(\mathrm{II})-\mathrm{Ni}(\mathrm{II})$.

In the present paper, the authors investigated the dependence of the physical and chemical properties of two types of PVC-based membranes on their chemical composition and their efficiency in $\mathrm{Zn}(\mathrm{II})$ ion separation in transport across the membranes. The membranes were obtained by solution casting method. Acetylacetone (ACAC) and di(2-ethylhexyl)phosphoric acid ( $\left.\mathrm{D}_{2} \mathrm{EHPA}\right)$ were used as the cation carriers. The membranes were also studied in order to obtain information on their structure. The membrane morphology (pore size and roughness) was investigated by atomic force microscopy (AFM). Such mechanical properties as thickness, tensile strength, and glass transition temperature, were also investigated. An attempt was made to explain the influence of the physical and chemical properties of the membranes on $\mathrm{Zn}(\mathrm{II})$ ion transport efficiency.

The structure of the PVC membranes has so far only been studied for commercial carriers (Aliquat 336, TOA, Cyphos ${ }^{\circledR}$ IL 104, $\mathrm{D}_{2}$ EHPA) $[4,37,42]$.

\section{Experimental}

\subsection{Reagents}

The inorganic chemicals, i.e., ammonia as well as ammonium nitrate, sodium nitrate and nitric acid were of analytical grade and were purchased from Avantor Company (Gliwice, Poland). Zinc(II) nitrate standard solution (1000 mg/L) was purchased from Sigma-Aldrich Company (Poznan, Poland). The aqueous solutions were prepared with a double-distilled water the conductivity of which was $0.1 \mathrm{~S} / \mathrm{m}$.

The organic reagent, i.e., polyvinyl chloride (PVC) suspension, with an average molecular weight of 72,000, was obtained from ANWIL Company, Wloclawek, Poland. Acetylacetone (ACAC) and tetrahydrofurane (both of analytical grade) were purchased from Avantor Company (Gliwice, Poland) and were used without further purification. The di(2-ethylhexyl)phosphoric acid $\left(\mathrm{D}_{2} \mathrm{EHPA}\right)$ and bis(2-ethylhexyl)adipate (DAO) were purchased from Sigma-Aldrich Company (Poznan, Poland).

\subsection{Membrane Preparation and Transport Experiments}

At first, a ternary mixture in tetrahydrofurane was prepared using PVC, DAO, and ACAC (Figure $1 \mathrm{~A}$ ) or $\mathrm{D}_{2}$ EHPA (Figure $1 \mathrm{~B}$ ) as ion carrier.

The obtained mixture was poured out on an ANUMBRA self-levelling dish. After the evaporation of the tetrahydrofurane, $24 \mathrm{~h}$ later, the membranes were removed from the glass surface and immersed 
in distilled water for $12 \mathrm{~h}$ to obtain a homogeneous film structure. A total of eleven different membranes was obtained. Their quantitative compositions are presented in Table 1. In order to initiate the process of transport twice in the same conditions, in the case of each membrane, two samples were cut out from the original membrane films.<smiles>CC(=O)CC(C)=O</smiles>

(A)

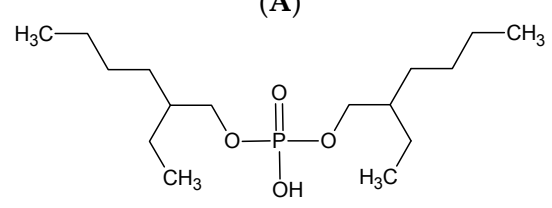

(B)

Figure 1. Structure of acetylacetone (A) and di(2-ethylhexyl) phosphoric acid (B).

Table 1. Compositions of investigated membranes.

\begin{tabular}{cccccccccccc}
\hline Membrane, No. & $\mathbf{1}$ & $\mathbf{2}$ & $\mathbf{3}$ & $\mathbf{4}$ & $\mathbf{5}$ & $\mathbf{6}$ & $\mathbf{7}$ & $\mathbf{8}$ & $\mathbf{9}$ & $\mathbf{1 0}$ & $\mathbf{1 1}$ \\
\hline Matrix, PVC, \% & 90 & 70 & 50 & 40 & 30 & 20 & 95 & 75 & 55 & 45 & 35 \\
Plasticizer, DAO, \% & 10 & 10 & 10 & 10 & 10 & 10 & 5 & 5 & 5 & 5 & 5 \\
Carrier & \multicolumn{9}{c}{ acac } & & \multicolumn{7}{c}{$\mathrm{D}_{2}$ EHPA } & \\
Carrier, \% & 0 & 20 & 40 & 50 & 60 & 70 & 0 & 20 & 40 & 50 & 60 \\
\hline
\end{tabular}

The transport experiments were carried out in a permeation module cell, which was presented in the authors' earlier paper [41]. The membrane film (having a surface area of $4.4 \mathrm{~cm}^{2}$ ) was tightly clamped between two cell compartments. Both the feed and the receiving aqueous phases $(45 \mathrm{~mL}$ each) were mechanically stirred at $600 \mathrm{rpm}$. Distilled water was used as the receiving phase. The PIMs transport experiments were carried out at $20 \pm 0.2{ }^{\circ} \mathrm{C}$. Small samples of the aqueous receiving phase were taken periodically via a sampling port, equipped with a syringe, and analyzed by atomic absorption spectroscopy (AAS Spectrometer, AAS 240FS, Agilent, Santa Clara, CA, USA) to determine zinc(II) concentration. The $\mathrm{pH}$ of the feed phase was kept constant using an ammonia buffer and controlled by means of a pH-meter ( $\mathrm{pH}$ meter, CX-731 Elmetron, Zabrze, Poland), with a combination pH electrode (ERH-126, Hydromet, Bytom, Poland).

\subsection{AFM Analysis}

The synthesized PIMs were examined by an Atomic-force MultiMode Scanning Probe Microscope IIIa (AFM) (Digital Instruments Veeco Metrology Group, Santa Barbara, CA, USA) operating in the tapping mode, in air, at a room temperature. The membranes were visualized in a two-dimensional and in a three-dimensional form, sizes $1.0 \times 1.0 \mu \mathrm{m}, 5.0 \times 5.0 \mu \mathrm{m}$ and $10.0 \times 10.0 \mu \mathrm{m}$.

\subsection{Tests of Mechanical Properties of PIMs}

Mean thickness of all membranes was determined after measuring the test samples with the manual precision thickness gauge Panametrics ${ }^{\circledR}$ Magna-Mike ${ }^{\circledR} 8500$ (San Diego, CA, USA). The mean value resulted from 10 measurements, made at randomly selected points located on the surface of each membrane.

Mechanical properties of the selected membranes were examined by static extension using the universal testing machine Z030 from Zwick/Roell (Ulm, Germany), equipped with a measurement head, at a nominal force of $500 \mathrm{~N}$. Extension rate during calculation of the modulus of elasticity was $1 \mathrm{~mm} / \mathrm{min}$. The extension test was then performed at a rate of $50 \mathrm{~mm} / \mathrm{min}$ until the breaking of the samples. The test samples were in the shape of a dumbbell, obtained by cut out from the membrane. The total sample length was $82 \mathrm{~mm}$ and the length of the part limited by parallel lines was $38 \mathrm{~mm}$. 
The sample width was $15 \mathrm{~mm}$ at the ends and $10 \mathrm{~mm}$ in its narrow section, the grips were $50 \mathrm{~mm}$ apart initially. The measurements were carried out at $20^{\circ} \mathrm{C}$. Mean values of the mechanical properties were determined based of the tests performed on 5 samples.

The glass-transition temperature of each membrane samples was measured by scanning differential calorimetry, using the DSC 2014 Polyma apparatus from Netzsch, Selb, Germany. The samples (7-9 mg) were heated under nitrogen atmosphere from room temperature to $120^{\circ} \mathrm{C}$ to remove any thermal or mechanical history of the material. Then, after being kept for $2 \mathrm{~min}$ in such temperature, the samples were cooled to $-50{ }^{\circ} \mathrm{C}$ and reheated to $120^{\circ} \mathrm{C}$ after a 2 -min isotherm. The heating and cooling rate was $10^{\circ} \mathrm{C} / \mathrm{min}$.

\section{Results and Discussion}

\subsection{Transport across PIMs Doped with Acac}

To determine the optimum $\mathrm{pH}$ of the feed phase and composition of the receiving phase, a preliminary transport test with PIMs doped with $20 \%$ of ACAC (2) was performed.

The $\mathrm{pH}$ of the feed phase was varied by addition of an ammonium buffer. The zinc ions concentration in the feed phase was measured after $24 \mathrm{~h}$ of the transport process. The zinc amount transported across the membrane was calculated from the formula:

$$
R F=\frac{c}{c_{0}} \cdot 100 \%
$$

where:

- $\quad R F-$-recovery factor of zinc ions;

- $c_{0}$-initial concentration of metal ions in the feed phase, $\mathrm{mol} / \mathrm{L}$;

- $\quad c$-concentration of metal ions in the receiving phase after time $\mathrm{t}, \mathrm{mol} / \mathrm{L}$.

It was found that the optimum $\mathrm{pH}$ of the feed phase for effective recovery of zinc (96\%) was 9.62 .

An excess of ammonia dissolves zinc hydroxide, which is formed in high $\mathrm{pH}$, leading to the formation of ammine complexes:

$$
\begin{gathered}
\mathrm{Zn}^{2+}+2 \mathrm{OH}^{-} \rightarrow \mathrm{Zn}(\mathrm{OH})_{2} \\
\mathrm{Zn}(\mathrm{OH})_{2}+4 \mathrm{NH}_{3} \rightarrow\left[\mathrm{Zn}\left(\mathrm{NH}_{3}\right)_{4}\right]^{2+}+2 \mathrm{OH}^{-} .
\end{gathered}
$$

At higher $\mathrm{pH}$ (of at least 9.6), the ACAC molecules which are present in the membrane become dissociated:<smiles>CC(=O)CC(CC#CCCC(=O)CC(C)O)OP</smiles>

and are able to form stable chelate complexes with $\mathrm{Zn}$ (II) ions. Such $\mathrm{pH}$ enables the metal ions to be transported across the PIMs.

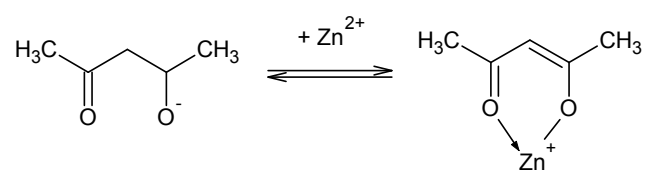

The amount of the recovered zinc also depends on the composition of the receiving phase. The effect of receiving phase composition on transport through the PIMs was evaluated using 
an ammonium buffered solution of $\mathrm{pH}=9.65$, distilled water $(\mathrm{pH}=6.94)$ and $0.5 \mathrm{M}$ nitric acid $(\mathrm{pH}=1.34)$. It was found that after a $24-\mathrm{h}$ process of $\mathrm{Zn}(\mathrm{II})$ ion transport across PIMs doped with $20 \%$ ACAC, the obtained values of $Z n$ recovery were $0.11 \%, 23.54 \%$, and $4.14 \%$, respectively.

In the subsequent $\mathrm{Zn}$ (II) ion ( $5 \mathrm{mM}$ ) transport experiments, involving PIMs doped with acac, a pH value of the feed phase was $9.62\left(\mathrm{NH}_{4} \mathrm{NO}_{3}: \mathrm{NH}_{3}\right)$ and the receiving phase was a distilled water at $\mathrm{pH} 6.94$.

The results obtained after $24 \mathrm{~h}$ of $\mathrm{Zn}(\mathrm{II})$ transport across PIMs doped with acac in relation to various amounts of carrier are shown in Table 2.

Table 2. Recovery factors (RF) for competitive transport of $\mathrm{Zn}$ (II) ions across polymer inclusion membranes (PIMs) with acac as a carrier. Membrane: PVC, 10\% DAO, and acac. Feed phase: $\mathrm{ZZn}(\mathrm{II})=5 \mathrm{mM}, \mathrm{pH}=9.62$; receiving phase: water.

\begin{tabular}{ccccccc}
\hline Membrane No. & $\mathbf{1}$ & $\mathbf{2}$ & $\mathbf{3}$ & $\mathbf{4}$ & $\mathbf{5}$ & $\mathbf{6}$ \\
\hline$\%$ ACAC & $0 \%$ & $20 \%$ & $40 \%$ & $50 \%$ & $60 \%$ & $80 \%$ \\
RF, $\%$ & 0.51 & 99.65 & 23.54 & 16.64 & 12.45 & 6.29 \\
\hline
\end{tabular}

The highest recovery of zinc(II) (99.65\%) was obtained in the case of membrane 2, containing $20 \%$ of ACAC.

\subsection{Transport across PIMs Doped with $D_{2} E H P A$}

$\mathrm{D}_{2} \mathrm{EHPA}$ is an acidic extractant. During the transport of $\mathrm{Zn}(\mathrm{II})$ ions across membranes doped with $\mathrm{D}_{2} \mathrm{EHPA}$, extraction and re-extraction take place at the same time, as shown by the reaction equations:

- $\quad$ at interface: feed phase/membrane:

$$
\mathrm{Zn}(\mathrm{II})+3 / 2(\mathrm{HR})_{2}=\mathrm{ZnR}_{2} \cdot \mathrm{HR}+2 \mathrm{H}^{+}
$$

- $\quad$ at interface: membrane/receiving phase:

$$
\mathrm{ZnR}_{2} \cdot \mathrm{HR}+2 \mathrm{H}^{+}=\mathrm{Zn}(\mathrm{II})+3 / 2(\mathrm{HR})_{2}
$$

where HR denotes carrier $\left(\mathrm{D}_{2} \mathrm{EHPA}\right)$ molecule.

The compositions of the feed phase and the receiving phase for PIMs doped with $\mathrm{D}_{2} \mathrm{EHPA}$ were the same as those reported by Kolev [37]. The feed phase contained $5 \mathrm{mM} \mathrm{Zn(II)} \mathrm{and} 4 \mathrm{mM} \mathrm{NaNO}_{3}$, its $\mathrm{pH}$ was maintained at 1.61 using $\mathrm{HNO}_{3}$, the receiving phase was $0.1 \mathrm{M} \mathrm{HNO}_{3}$.

The results of the experiments after $24 \mathrm{~h}$ of $\mathrm{Zn}$ (II) transport across PIMs doped with $\mathrm{D}_{2}$ EHPA for various carriers contents are shown in Table 3.

Table 3. Recovery factors (RF) for competitive transport of $\mathrm{Zn}(\mathrm{II})$ ions across PIMs with $\mathrm{D}_{2} \mathrm{EHPA}$ as a carrier. Membrane: PVC, $5 \%$ DAO, and $\mathrm{D}_{2}$ EHPA. Feed phase: $C_{\mathrm{Zn}(\mathrm{II})}=5 \mathrm{mM}, \mathrm{pH}=1.61$; receiving phase: $0.1 \mathrm{M} \mathrm{HNO}_{3}$.

\begin{tabular}{cccccc}
\hline Membrane No. & $\mathbf{7}$ & $\mathbf{8}$ & $\mathbf{9}$ & $\mathbf{1 0}$ & $\mathbf{1 1}$ \\
\hline$\% \mathrm{D}_{2}$ EHPA & $0 \%$ & $20 \%$ & $40 \%$ & $50 \%$ & $60 \%$ \\
$\mathrm{RF}, \%$ & 0.95 & 1.80 & 25.71 & 44.27 & 56.33 \\
\hline
\end{tabular}

The data in the Table 3 indicate that zinc(II) recovery increases with increasing concentrations of the $\mathrm{D}_{2}$ EHPA carrier in the membrane. The highest values of RF (56.33\%) were obtained for the membrane composed of $35 \% \mathrm{PVC}, 5 \% \mathrm{DAO}$, and $60 \% \mathrm{D}_{2} \mathrm{EHPA}$.

\subsection{Comparision of Acac and $D_{2}$ EHPA in the Transport across PIMs}

The transport of ions by means of carriers can be divided into following stages: 
- formation in the feed phase of a complex composed of the carried substance and the carrier;

- diffusion of the complex across the membrane into the receiving phase;

- decomposition of the complex compound and release of the transported substance into the receiving phase [9].

It was found that the maximum recovered amount of zinc(II), which depends on the carrier in the membrane, for PIMs doped with acac and with $\mathrm{D}_{2}$ EHPA was $99.6 \%$ and $56.33 \%$, respectively.

The maximum recovery of zinc(II) requires a $60 \%$ content of $\mathrm{D}_{2} \mathrm{EHPA}$ in the membrane while in the case of membranes with acac, a $20 \%$ carrier content is sufficient in order to obtain the same effect.

An effective transport of zinc ions takes place in acidic conditions for $\mathrm{D}_{2} \mathrm{EHPA}$ and in alkaline conditions for acac. The membranes can be used for zinc recovery from solutions obtained after leaching metal-bearing waste by means of an acid or ammonia. The choice between these two types of membranes for zinc recovery depends on the $\mathrm{pH}$ of the solution from which the ions are to be extracted. Zinc recovery by means of PIMs doped with $20 \%$ acac in alkaline conditions is twice as high as in the case of PIMs doped with $60 \% \mathrm{D}_{2}$ EHPA in acidic conditions.

\subsection{Membrane Morphology}

Membrane microstructure is one of major aspects affecting the separation of metal ions [42,43]. Supported liquid membranes (SLM) have a specific structure, depending on the particular type polymer film (polypropylene, polyamide, or other ones). Commercially available membrane sheets (such as Celgard 2400, Accurel, Goretex) have strictly defined parameters, namely: thickness, porosity, and pore size. In the case of PIMs, which are prepared by pouring out a polymer solution containing a plasticizer and carrier, the resulting membrane may have a different structure [44-47], depending on the type and concentration of the reactants [48]. Among all the techniques available for the examination of the surface of PIMs, scanning electron microscopy (SEM) and atomic force microscopy (AFM) are the most useful.

\subsubsection{PIMs Characterization by AFM}

Crucial information on the membrane uniformity, roughness, and pore size was obtained by means of AFM. The AFM topographic images of statistically selected membrane areas of all membranes were recorded.

The $2 \mathrm{D}$ and $3 \mathrm{D}$ images of membranes ( 1 and 7 ) with no carrier, with acac and with $\mathrm{D}_{2} \mathrm{EHPA}$ as carrier are shown in Figures 2-4, respectively.

$2 \mathrm{D}$

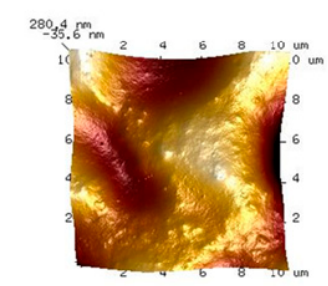

1

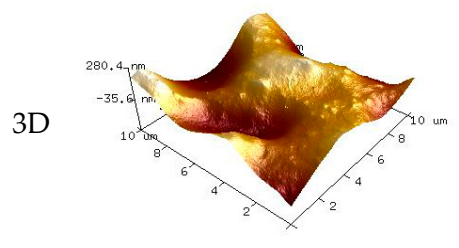

1

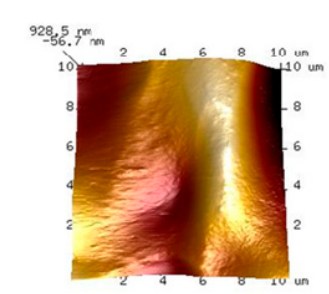

7

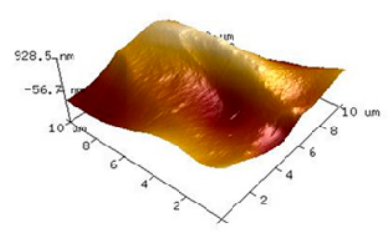

7

Figure 2. 2D and 3D-atomic force microscopy (AFM) images of PIMs with no carriers: (1) and (7).

The membranes with no carrier are smooth, without visible pores (Figure 2). 
The AFM images in Figures 2-4 indicate that the carrier distribution in the investigated membranes, after the evaporation of solvent, is homogeneous throughout the entire surface. The surface morphology of the membrane is characterized by rough areas. This is due to either a different speed of the solvent evaporation or the membrane having a porous structure, where the pores were filled DAO, ACAC or $\mathrm{D}_{2}$ EHPA. The uniform parts of the membranes have well-defined pores. The pores are clearly visible as small, dark areas.

\subsubsection{Membrane Pore Size}

The pore diameters and roughness of the PIMs were calculated using the Nanoscope Analysis 1.40 Software (Billerica, USA). In both membrane types the number of pores is rather small. The pore size in the membranes with no carrier (1 and 7) ranges between 3.403 and $7.215 \mu \mathrm{m}$ and between 4.831 and $7.445 \mu \mathrm{m}$, respectively. The membranes have different concentrations of the DAO plasticizer. As expected, the pore sizes in the membrane with $5 \%$ DAO are greater than those in the membrane with $10 \%$ DAO. The introduction of carrier into the membranes affected pore dimensions. For the membranes with acac as carrier, the pore sizes increased with increasing ACAC content in the membrane, from 3.201-5.133 $\mu \mathrm{m}$ in the case of the membrane with $20 \%$ ACAC (2) to $6.400-6.628 \mu \mathrm{m}$ in the case of the PIM with $70 \%$ acac (6). In the membranes with $\mathrm{D}_{2} \mathrm{EHPA}$ as carrier, the pore sizes decreased negligibly with increasing $\mathrm{D}_{2}$ EHPA content in the membrane, from 4.831-7.445 $\mu \mathrm{m}$ for the membranes with $20 \% \mathrm{D}_{2} \mathrm{EHPA}$ (8) to $2.638-2.839 \mu \mathrm{m}$ for the PIM with $60 \% \mathrm{D}_{2} \mathrm{EHPA}(\mathbf{1 1})$.

$2 \mathrm{D}$

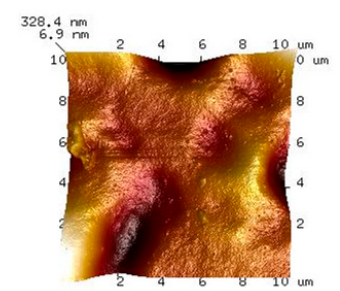

2

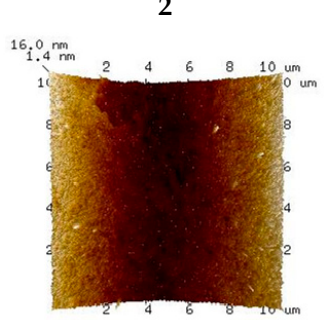

5

$3 \mathrm{D}$

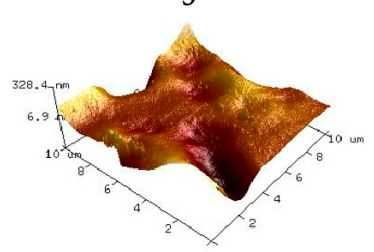

2

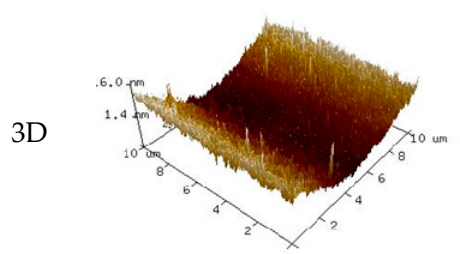

5

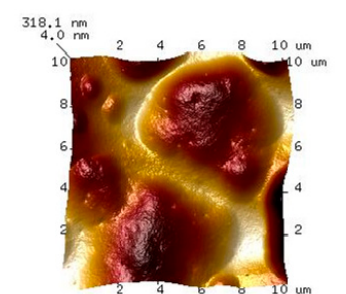

3

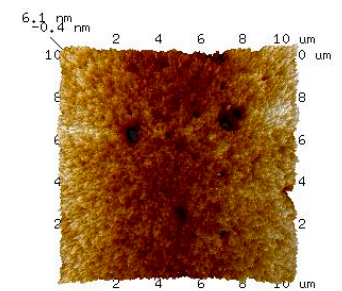

6

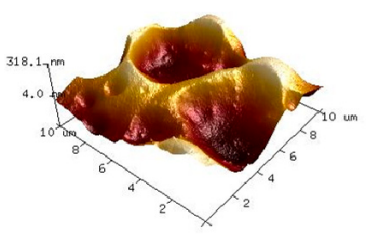

3

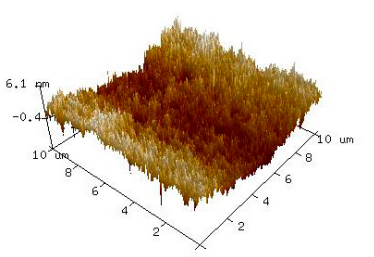

6

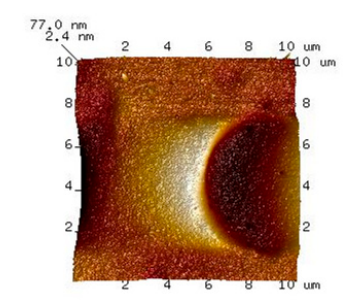

4

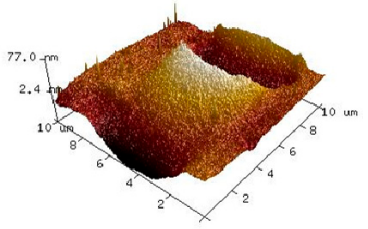

4

Figure 3. 2D and 3D-atomic force microscopy (AFM) images of PIMs with an increasing percentage of carrier (acac): (2), (3), (4), (5), and (6), the composition of membranes is given in Table 2. 
2D

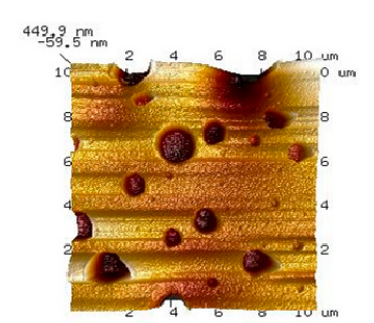

8

$2 \mathrm{D}$

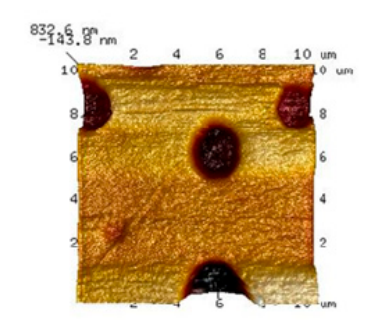

10

3D

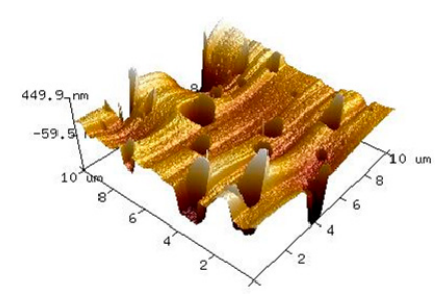

8

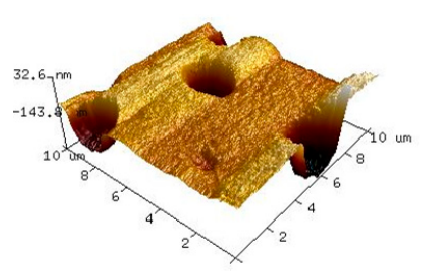

10

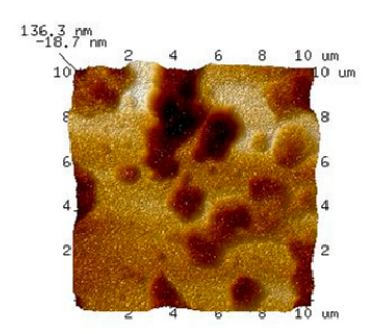

9

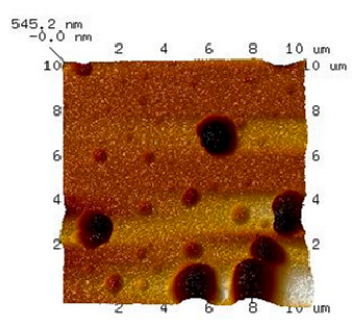

11

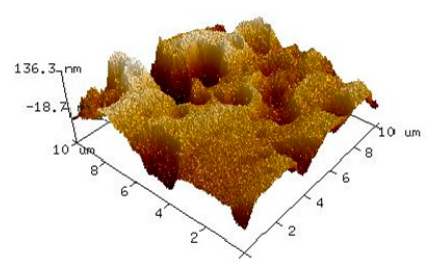

9

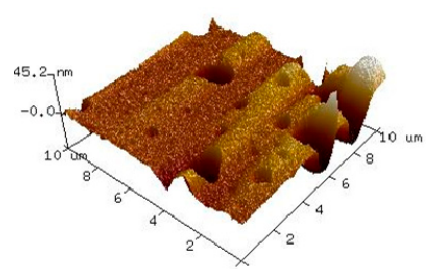

11

Figure 4. 2D and 3D-atomic force microscopy (AFM) images of PIMs with an increasing percentage of carrier ( $\left.\mathrm{D}_{2} \mathrm{EHPA}\right):(\mathbf{8}),(\mathbf{9}),(\mathbf{1 0})$, and (11), the composition of membranes is given in Table 3.

The most effective zinc transport was observed in relation to membranes $\mathbf{2}(\mathrm{RF}=99.65 \%)$ and $\mathbf{1 1}$ $(\mathrm{RF}=56.33 \%)$, in the case of which the pore sizes were the smallest among the investigated membranes. The membranes with more than 20\% ACAC content (3-6), during the transport of $\mathrm{Zn}$ (II) ions suffered from fouling of surfaces by substances depositing in the pores (fouling phenomenon). This resulted in higher membrane resistance, leading to lower efficiency of the transport process $[6,49,50]$.

\subsubsection{Membrane Roughness}

Mean roughness values for both membrane types, calculated based on three independent measurements, are shown in Table 4.

Table 4. Mean roughness (RF) of PIMs.

\begin{tabular}{cccccccccccc}
\hline Membrane No. & $\mathbf{1}$ & $\mathbf{2}$ & $\mathbf{3}$ & $\mathbf{4}$ & $\mathbf{5}$ & $\mathbf{6}$ & $\mathbf{7}$ & $\mathbf{8}$ & $\mathbf{9}$ & $\mathbf{1 0}$ & $\mathbf{1 1}$ \\
\hline $\mathrm{RF}, \mathrm{nm}$ & 2.91 & 4.71 & 3.86 & 2.23 & 3.55 & 1.66 & 1.62 & 2.42 & 3.09 & 5.82 & 6.15 \\
\hline \multicolumn{8}{c}{ The composition of membranes is given in Tables 2 and 3.}
\end{tabular}


Carriers such as acac and $\mathrm{D}_{2} \mathrm{EHPA}$ tend to crystallize in the membrane, causing roughness and diversified porosity. In addition, $\mathrm{D}_{2} \mathrm{EHPA}$ may function as a plasticizer and its molecules preferentially migrate to the membrane surface, increasing its roughness. An increase in roughness due to the presence of carrier, which could act as a plasticizer, was observed in relation to CTA-based membranes with the commercial carrier TOA [51] as well as in the case of PVC-based membranes with Aliquat 336 as carrier [42]. This was also reported in the works [41] concerning the application of such membranes in surface water treatment.

Although the two polymer membrane types (with ACAC and $\mathrm{D}_{2} \mathrm{EHPA}$ as a carriers) have different roughness, the values are very low, in the range of a few nanometers. Surface roughness accounts for local flowrate problems, therefore, the membrane surface should be as uniform and smooth as possible.

The determined roughness values reflect the pore numbers in the test membranes and correspond well with the results of zinc(II) ion transport.

\subsection{Characterization of Mechanical Properties of PIMs}

\subsubsection{Membrane Thickness}

Mean thickness of the membranes and standard deviations are shown in Table 5.

As shown in Table 5, the membranes with acac as carrier (2-6) were thicker than those with $\mathrm{D}_{2}$ EHPA as carrier (8-11). In the case of both membrane types, thickness was observed to decrease with increasing carrier percentages.

Table 5. Mean thickness of membrane test samples.

\begin{tabular}{cccccccccccc}
\hline Membrane No. & $\mathbf{1}$ & $\mathbf{2}$ & $\mathbf{3}$ & $\mathbf{4}$ & $\mathbf{5}$ & $\mathbf{6}$ & $\mathbf{7}$ & $\mathbf{8}$ & $\mathbf{9}$ & $\mathbf{1 0}$ & $\mathbf{1 1}$ \\
\hline $\begin{array}{c}\text { Mean membrane } \\
\text { thickness, mm }\end{array}$ & 0.242 & 0.292 & 0.281 & 0.273 & 0.271 & 0.269 & 0.185 & 0.194 & 0.196 & 0.187 & 0.179 \\
\hline Standard deviation & 0.050 & 0.038 & 0.041 & 0.046 & 0.011 & 0.017 & 0.080 & 0.030 & 0.043 & 0.018 & 0.047 \\
\hline \multicolumn{1}{c}{ The composition of membranes is given in Tables 2 and 3. } \\
\hline
\end{tabular}

\subsubsection{Resistance to Static Extension}

The results of the tests of mechanical properties for selected membranes are shown in Table 6.

The highest modulus of elasticity at static extension was determined for the PVC-based membrane with 5\% DAO with no carrier (7) and the PVC-based membrane with 5\% DAO and $20 \% \mathrm{D}_{2} \mathrm{EHPA}$ (8). These moduli equaled 794 and $747 \mathrm{MPa}$, respectively, for 7 and 8. The other membranes were characterized by clearly lower values of Young's modulus. Its value was the lowest in relation to the membranes containing acac as carrier, for instance membrane 2 (36 MPa), and membrane 1 with $10 \% \mathrm{DAO}$ with no carrier $(61 \mathrm{MPa})$. The membranes which were characterized by lower stiffness clearly showed higher values of strain at break, namely $240 \%$ and more, while for the membranes with higher value of tensile modulus the values of strain at break were lower than $200 \%$.Moreover, membranes 7 and $\mathbf{8}$ have a different stress-strain curve profile, with a clearly visible yield point (Figure 5). In the other cases, no maximum value was observed on the curves showing the stress-strain relationship.

Table 6. Mechanical properties of selected membranes, as determined in static extension tests at $20{ }^{\circ} \mathrm{C}$.

\begin{tabular}{cccc}
\hline Membrane & Young's Modulus (Mpa) & Tensile Strength (Mpa) & Strain at Break (\%) \\
\hline $\mathbf{1}$ & 61 & 17.5 & 240 \\
$\mathbf{2}$ & 36 & 14.6 & 279 \\
$\mathbf{4}$ & 58 & 15.7 & 264 \\
$\mathbf{7}$ & 794 & $17.1^{*}$ & 127 \\
$\mathbf{8}$ & 747 & $18.1^{*}$ & 191 \\
\hline
\end{tabular}

* Yield stress. The composition of membranes is given in Tables 2 and 3. 


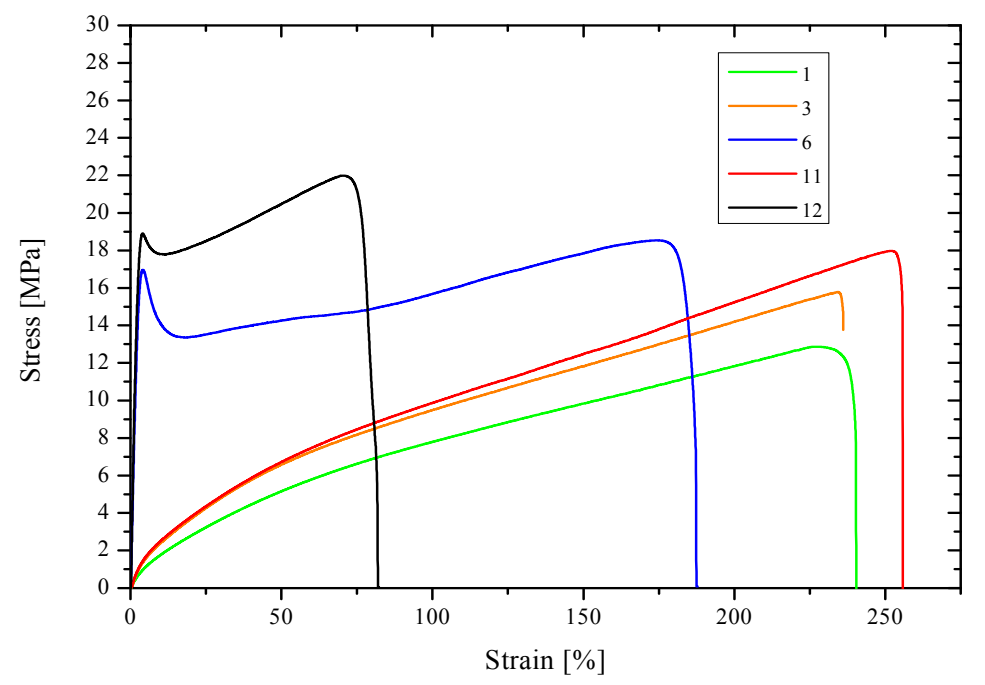

Figure 5. Examples of extension curves for the test membranes. The composition of membranes is given in Tables 2 and 3.

The test samples of membrane 8 were observed to have the optimum tensile strength (18.1 MPa). Tensile strength, however, is not directly linked with the value of Young's modulus, as proved in the case of membrane 1 : its tensile strength is $17.5 \mathrm{MPa}$ even though its rigidity is quite low.

\subsubsection{Membrane Glass-Transition Temperature}

In relation to the membranes where acac is the carrier (2-6) and to the one with $10 \%$ of plasticizer (1) and no carrier, glass-transition temperature was not recorded between -50 and $120{ }^{\circ} \mathrm{C}$. For membranes 8-11 with $\mathrm{D}_{2} \mathrm{EHPA}$ as carrier, glass-transition temperature was in the range between 62.9 and $71.2^{\circ} \mathrm{C}$ and increased with an increase in the carrier content in the membrane.

\section{Conclusions}

PIMs based on PVC with no carrier form a thin film with no visible pores. The membranes have a porous structure only after an addition of ACAC or $\mathrm{D}_{2} \mathrm{EHPA}$. The pores are irregular and few micrometers in size.

In the case of membranes with ACAC as carrier, pore sizes increase with increasing content of ACAC in the membrane. In contrast, in the case of membranes with $\mathrm{D}_{2} \mathrm{EHPA}$ as carrier, pore sizes slightly decrease as the $\mathrm{D}_{2}$ EHPA content in the membrane increases.

The two investigated polymer membrane types are characterized by different, though in both cases very low, values of roughness, amounting only to a few nanometers. Surface roughness accounts for local flowrate problems, therefore, the membrane surfaces should be uniform and smooth as possible.

Zinc ions are best transported through membranes with $20 \%$ acac or $60 \% \mathrm{D}_{2}$ EHPA. They have the lowest pore sizes.

The zinc ion transport is effective in acidic conditions for $\mathrm{D}_{2} \mathrm{EHPA}$ and in alkaline conditions for ACAC. The membranes can be used for zinc recovery from solutions obtained after leaching metal-bearing waste with an acid or ammonia. The choice between these two types of membranes for zinc recovery depends on the $\mathrm{pH}$ of the solution from which the ions are to be extracted. Zinc recovery by means of PIMs doped with 20\% ACAC in alkaline conditions is twice as high as in the case of PIMs doped with $60 \% \mathrm{D}_{2}$ EHPA in acidic conditions.

In the case of membranes containing more than $20 \%$ ACAC, surface fouling was observed as substances deposited in the pores during the transport of $\mathrm{Zn}$ (II) ions. This resulted in higher membrane resistance, leading to lower efficiency of the transport process. 
In relation to membranes with $\mathrm{D}_{2} \mathrm{EHPA}$ as carrier, zinc recovery increases with increasing concentration of the carrier in the membrane.

Acknowledgments: The new developments presented above were carried out within the 2007-2013 Innovative Economy Operational Programme, Sub-action 1.3.2., Support of the protection of industrial property generated by scientific entities as a result of R\&D works within project No. UDA-POIG.01.03.02-04-077/12-01, financed by the European Regional Development Fund (ERDF) (85\% of co-financing) and from a designated subsidy (15\% of co-financing).

Author Contributions: Katarzyna Witt conceived and designed greater part of the experiments; Katarzyna Witt performed the experiments of zinc ions transport; Artur Kosciuszko performed the experiments of mechanical and thermal properties of the membranes; Magdalena Gierszewska performed the experiments of membrane morphology; Kamil Ziuziakowski performed the atomic absorption spectroscopy (AAS) analysis; Katarzyna Witt, Elzbieta Radzyminska-Lenarcik, Artur Kosciuszko and Magdalena Gierszewska analyzed the data; Katarzyna Witt contributed reagents/materials; Elzbieta Radzyminska-Lenarcik proposed the concept of publication and wrote the greater part of the paper (introduction, results, discussion and conclusion).

Conflicts of Interest: The authors declare no conflict of interest.

\section{References}

1. Bloch, R.; Kedem, O.; Vofsi, D. Ion specific polymer membrane. Nature 1963, 199, 802-803. [CrossRef] [PubMed]

2. Sugiura, M.; Kikkawa, M.; Urita, S. Carrier-mediated transport of rare earth ions through cellulose triacetate membranes. J. Membr. Sci. 1989, 42, 47-55. [CrossRef]

3. Kaya, A.; Alpoguz, H.K.; Yilmaz, A. Application of $\mathrm{Cr}(\mathrm{VI})$ Transport through the Polymer Inclusion Membrane with a New Synthesized Calix[4]arene Derivative. Ind. Eng. Chem. Res. 2013, 52, 5428-5436. [CrossRef]

4. Nutchapurida Bonggotgetsakul, Y.Y.; Cattrall, R.W.; Kolev, S.D. Extraction of Gold(III) from Hydrochloric Acid Solutions with a PVC-based Polymer Inclusion Membrane (PIM) Containing Cyphos ${ }^{\circledR}$ IL 104. Membranes 2015, 5, 903-914. [CrossRef] [PubMed]

5. Casadellà, A.; Schaetzle, O.; Nijmeijer, K.; Loos, K. Polymer Inclusion Membranes (PIM) for the Recovery of Potassium in the Presence of Competitive Cations. Polymers 2016, 8, 76. [CrossRef]

6. Drioli, E.; Strathmann, H.; Giorno, L. Basic aspects in polymeric membrane preparation. In Comprehensive Membrane Science and Engineering, 1st ed.; Drioli, E., Giorno, L., Eds.; Elsevier: Milan, Italy, 2010. ISBN 978-0-444-53204-6.

7. Religa, P.; Rajewski, J.; Gierycz, P. Advantages and disadvantages of SLM and PIM systems used for chromium(III) separation from aqueous solutions. Pol. J. Environ. Stud. 2015, 24, 1283-1290.

8. Inês, M.; Almeida, G.S.; Cattrall, R.W.; Kolev, S.D. Recent trends in extraction and transport of metal ions using polymer inclusion membranes (PIMs). J. Membr. Sci. 2012, 415-416, 9-23. [CrossRef]

9. Nghiem, L.D.; Mornane, P.; Potter, I.D.; Perera, J.M.; Cattrall, R.W.; Kolev, S.D. Extraction and transport of metal ions and small organic compounds using polymer inclusion membranes (PIMs). J. Membr. Sci. 2006, 281,7-41. [CrossRef]

10. Annane, K.; Sahmoune, A.; Montels, P.; Tingry, S. Polymer inclusion membrane extraction of cadmium(II) with Aliquat 336 in micro-channel cell. Chem. Eng. Res. Des. 2015, 94, 605-610. [CrossRef]

11. Baczyńska, M.; Regel-Rosocka, M.; Nowicki, M.; Wiśniewski, M. Effect of the structure of polymer inclusion membranes on $\mathrm{Zn}$ (II) transport from chloride aqueous solutions. J. Appl. Polym. Sci. 2015, 132, 42319-42329. [CrossRef]

12. Hosseini, S.S.; Bringas, E.; Tan, N.R.; Ortiz, I.; Ghahramani, M.; Shahmirzadi, M.A.A. Recent progress in development of high performance polymeric membranes and materials for metal plating wastewater treatment: A review. J. Water Process Eng. 2016, 9, 78-110. [CrossRef]

13. Narębska, A. Wprowadzenie do technik membranowych. Podstawowe prawa transportu. In Membrany I Membranowe Techniki Rozdziału, 1st ed.; Narębska, A., Ed.; Wydawnictwo UMK: Torun, Poland, 1997. ISBN 83-231-0937-0.

14. Senhadji-Kebiche, O.; Belaid, T.; Benamor, M. Polymer Inclusion Membrane (PIM) as Competitive Material for Applications in SPE for Water Treatment Process. Open Access Libr. J. 2014, 1, 1-7. [CrossRef] 
15. Ulewicz, M.; Radzyminska-Lenarcik, E. Supported Liquid (SLM) and Polymer Inclusion (PIM) Membranes Pertraction of Copper(II) from Aqueous Nitrate Solutions by 1-Hexyl-2-Methylimidazole. Sep. Sci. Technol. 2012, 47, 1383-1389. [CrossRef]

16. Kumari, A.; Sinha, M.K.; Sahu, S.K.; Pandey, B.D. Solvent extraction and separation of tri-valent lanthanides using Cyphos IL 104, A novel phosphonium ionic liquid as extractant. Solvent Extr. Ion Exch. 2016, 34, 469-484. [CrossRef]

17. Cieszynska, A.; Wisniewski, M. Extraction of palladium(II) from chloride solutions with Cyphos ${ }^{\circledR}$ IL 101/toluene mixtures as novel extractant. Sep. Purif. Technol. 2010, 73, 202-207. [CrossRef]

18. Araki, T.; Tsukube, H. Liquid Membranes: Chemical Applications; CRC Press: Boca Raton, FL, USA, 1990.

19. Saf, A.Ö.; Alpaydin, S.; Coskun, A.; Ersoz, M. Selective transport and removal of $\mathrm{Cr}(\mathrm{VI})$ through polymer inclusion membrane containing 5-(4-phenoxyphenyl)-6H-1,3,4-thiadiazin-2-amine as a carrier. J. Membr. Sci. 2011, 377, 241-248. [CrossRef]

20. Sgarlata, C.; Arena, G.; Longo, E.; Zhang, D.; Yang, Y.; Bartsch, R.A. Heavy metal separation with polymer inclusion membranes. J. Membr. Sci. 2008, 323, 444-451. [CrossRef]

21. Ceynowa, J. Membrany selektywne i procesy membranowe. In Membrany Teoria i Praktyka; Zeszyt, I., Wodzki, R., Eds.; Wydział Chemii, Uniwersytet Mikołaja Kopernika: Torun, Poland, 2003. ISBN 83-231-1604-0.

22. Godlewski, M. Zinc oxide for electronic, photovoltaic and optoelectronic applications. J. Low Temp. Phys. 2011, 37, 235-240. [CrossRef]

23. Councell, T.B.; Duckenfield, K.U.; Landa, E.R.; Callender, E. Tire-Wear Particles as a Source of Zinc to the Environment. Environ. Sci. Technol. 2004, 38, 4206-4214. [CrossRef] [PubMed]

24. Silva, L.F.O.; Oliveira, M.L.S.; Serra, C.; Hower, J.C. Zinc Speciation in Power Burning Mixturea of Coal and Tires. Coal Combust. Gasif. Prod. 2011, 3, 41-50. [CrossRef]

25. Radzymińska-Lenarcik, E.; Sulewski, M.; Urbaniak, W. Recovery of Zinc from Metallurgic Waste Sludges. Pol. J. Environ. Stud. 2015, 24, 1277-1282. [CrossRef]

26. Biswas, R.K.; Karmakar, A.K.; Kumar, S.L.; Hossain, M.N. Recovery of manganese and zinc from waste Zn-C cell powder: Characterization and leaching. Waste Manag. 2015, 46, 529-535. [CrossRef] [PubMed]

27. Varghese, V.; Revanna, M.; Kiran, R.; Shivakumar, C.; Kumar, D. Hydrometallurgical Recovery of Zinc from Zinc Ash, Silver from Waste X-ray and Photographic Films. Int. J. Adv. Res. Technol. 2015, 4, 878-885.

28. European Council. Dyrektywa 2000/60/WE Parlamentu Europejskiego i Rady z dnia 23 Października 2000 r; European Council: Bruxelles, Belgium, 2000.

29. Cabała, J. Cynk w technosferze. Górnictwo Geol. 2010, 5, 63-76.

30. Gherasim, C.-V.; Cristea, M.; Grigoras, C.-V.; Bourceanu, G. New polymer inclusion membrane. Preparation and characterization. Dig. J. Nanomater. Biostruct. 2011, 6, 1507-1516.

31. Yilmaza, A.; Arslana, G.; Tor, A.; Akin, I. Selectively facilitated transport of Zn(II) through a novel polymer inclusion membrane containing Cyanex 272 as a carrier reagent. Desalination 2011, 277, 301-307. [CrossRef]

32. Resina, M.; Macanas, J.; de Gyves, J.; Munoz, M. Zn(II), Cd(II) and Cu(II) separation through organic-inorganic Hybrid Membranes containing di-(2-ethylhexyl) phosphoric acid or di-(2-ethylhexyl) dithiophosphoric acid as a carrier. J. Membr. Sci. 2006, 268, 57-64. [CrossRef]

33. Kozlowski, C.A. Facilitated transport of metal ions through composite and polymer inclusion membranes. Desalination 2006, 198, 132-140. [CrossRef]

34. Pranolo, Y.; Zhu, Z.; Cheng, C.Y. Separation of lithium from sodium in chloride solutions using SSX systems with LIX 54 and Cyanex 923. Hydrometallurgy 2015, 154, 33-39. [CrossRef]

35. Wejman-Gibas, K.; Pilsniak-Rabiega, M.; Ochromowicz, K. solvent extraction of zinc(II) from ammonia leaching solution by LIX 54-100, LIX 84 I and TOA. Physicochem. Probl. Miner. Process. 2017, 53, 202-211. [CrossRef]

36. Kebiche-Senhadji, O.; Mansouri, L.; Tingry, S.; Seta, P.; Benamora, M. Facilitated Cd(II) transport across CTA polymer inclusion membrane using anion (Aliquat 336) and cation $\left(\mathrm{D}_{2} \mathrm{EHPA}\right)$ metal carriers. J. Membr. Sci. 2008, 310, 438-445. [CrossRef]

37. Kolev, S.D.; Baba, Y.; Cattrall, R.W.; Tasaki, T.; Pereira, N.; Perera, J.M.; Stevens, G.W. Solid phase extraction of zinc(II) using a PVC-based polymer inclusion membrane with di(2-ethylhexyl)phosphoric acid (D2EHPA) as the carrier. Talanta 2009, 78, 795-799. [CrossRef] [PubMed] 
38. Baczyńska, M.; Regel-Rosocka, M.; Coll, M.T.; Fortuny, A.; Sastre, A.M.; Wiśniewski, M. Transport of Zn(II), $\mathrm{Fe}(\mathrm{II}), \mathrm{Fe}(\mathrm{III})$ across polymer inclusion membranes (PIM) and flat sheet supported liquid membranes (SLM) containing phosphonium ionic liquids as metal ion carriers. Sep. Sci. Technol. 2016, 51, 2639-2648. [CrossRef]

39. Arslana, G.; Y1lmazb, A.; Torc, A.; Ersoz, M. Preparation of polymer inclusion membrane with sodium diethyldithiocarbamate as a carrier reagent for selective transport of zinc ions. Desalination Water Treat. 2017, 75, 348-356. [CrossRef]

40. Radzyminska-Lenarcik, E.; Ulewicz, M. The use of 1-alkylimidzoles for selective separation of zinc ions in the transport process across a polymeric inclusion membrane. Physicochem. Probl. Miner. Process. 2014, 50, 131-142. [CrossRef]

41. Witt, K.; Radzyminska-Lenarcik, E.; Urbaniak, W. Selective transport of zinc ions through novel polymer inclusion membranes (PIMs) containing $\beta$-diketone derivatives as carrier reagents. Sep. Sci. Technol. 2016, 51, 2620-2627. [CrossRef]

42. Xu, J.; Wang, L.; Shen, W.; Paimin, R.; Wang, X. The Influence of the Interior Structure of Aliquat 336/PVC Membranes to their Extraction Behavior. Sep. Sci. Technol. 2005, 39, 3527-3539. [CrossRef]

43. Gherrou, A.; Kerdjoudj, H.; Molinari, R.; Seta, P.; Drioli, E. Fixed sites plasticized cellulose triacetate membranes containing crown ethers for silver(I), copper(II) and gold(III) ions transport. J. Membr. Sci. 2004, 228, 149-157. [CrossRef]

44. Gherrou, A.; Kerdjoudj, H.; Molinari, R.; Drioli, E. Modelization of the transport of silver and copper in acidic thiourea medium through a supported liquid membrane. Desalination 2001, 139, 317-325. [CrossRef]

45. Arous, O.; Kerdjoudj, H.; Seta, P. Comparison of carrier-facilitated silver (I) and copper (II) ions transport mechanisms in a supported liquid membrane and in a plasticized cellulose triacetate membrane. J. Membr. Sci. 2004, 241, 177-185. [CrossRef]

46. Arous, O.; Amara, M.; Kerdjoudj, H. Synthesis and characterization of cellulose triacetate and poly(ethylene imine) membranes containing a polyether macrobicyclic: Their application to the separation of copper(II) and silver(I) ions. J. Appl. Polym. Sci. 2004, 93, 1401-1410. [CrossRef]

47. Tor, A.; Arslan, G.; Muslu, H.; Celiktas, A.; Cengeloglu, Y.; Ersoz, M. Facilitated transport of Cr(III) through polymer inclusion membrane with di(2-ethylhexyl)phosphoric acid (DEHPA). J. Membr. Sci. 2004, 329, 169-174. [CrossRef]

48. Walkowiak, W.; Bartsch, R.A.; Kozlowski, C.; Gega, J.; Charewicz, W.; Amiri-Eliasi, B. Separation and removal of metal ionic species by polymer inclusion membrane. J. Radioanal. Nucl. Chem. 2000, 246, 643-650. [CrossRef]

49. Boussu, K.; Vandecasteele, B.; Van der Bruggen, B. Relation between membrane characteristics and performance in nanofiltration. J. Membr. Sci. 2008, 310, 51-65. [CrossRef]

50. Boussu, K.; Belpaire, A.; Volodin, A.; Van Haesendonck, C.; Van der Meerenc, P.; Vandecasteele, C.; Van der Bruggen, B. Influence of membrane and colloid characteristics on fouling of nanofiltration membranes. J. Membr. Sci. 2007, 289, 220-230. [CrossRef]

51. Kozlowski, C.A.; Walkowiak, W. Transport of Cr(VI), Zn(II), and Cd(II) Ions Across Polymer Inclusion Membranes with Tridecyl(pyridine) Oxide and Tri- $n$-Octylamine. Sep. Sci. Technol. 2004, 39, 3127-3141. [CrossRef]

(C) 2018 by the authors. Licensee MDPI, Basel, Switzerland. This article is an open access article distributed under the terms and conditions of the Creative Commons Attribution (CC BY) license (http://creativecommons.org/licenses/by/4.0/). 